\title{
Paraoxonase 1 Gene Polymorphisms (Q192R and L55M) Are Associated with Coronary Artery Disease Susceptibility in Asian Indians
}

\author{
Sumanpreet Kaur ${ }^{a} \quad$ Gurjit Kaur Bhatti $^{b}$ Rajesh Vijayvergiyac Puneetpal Singh ${ }^{d}$ \\ Sarabjit Singh Mastana ${ }^{e}$ Rupinder Tewari ${ }^{\mathrm{a}}$ Jasvinder Singh Bhatti ${ }^{f}$ \\ ${ }^{a}$ Department of Microbial Biotechnology, Panjab University, Chandigarh, India; ${ }^{b}$ UGC Centre of Excellence in \\ Nanoapplications, Panjab University, Chandigarh, India; ' ${ }^{C}$ epartment of Cardiology, Postgraduate Institute of \\ Medical Education and Research, Chandigarh, India; ${ }^{\mathrm{D}}$ Department of Human Genetics, Punjabi University, Patiala,

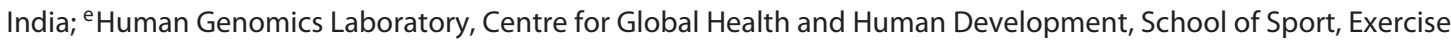 \\ and Health Sciences, Loughborough University, Loughborough, UK; ' Department of Biotechnology, Sri Guru \\ Gobind Singh College, Chandigarh, India
}

\section{Keywords}

Paraoxonase 1 - Gene variants · Coronary artery disease · Asian Indians

\section{Abstract \\ Background: Coronary artery disease (CAD) is a complex metabolic disorder in which lifestyle and genetic factors are known to play key roles in pathogenesis. The paraoxonase 1 (PON1) enzyme has a defensive effect against CAD progres- sion, as it safeguards low-density lipoproteins (LDLs) from oxidative modifications. The most extensively studied ge- netic variants in the PON1 gene are Q192R and L55M, which have been related with LDL antioxidative activity and risk of CAD. Objective: The present case-control study intended to examine the Q192R and L55M polymorphisms and their as- sociation with the risk of CAD patients in north Indians. Methods: A total of 872 subjects (412 CAD patients and 460 controls) were recruited from north India. The PON1 gene was amplified and genotypes were studies using PCR-RFLP. $X^{2}$ analysis was performed to compare genotype/allele fre- quencies in patients and controls. Results: The present study}

\begin{tabular}{ll}
\hline KARGER & ( 2018 The Author(s) \\
& Published by S. Karger AG, Basel Oparger \\
E-Mail karger@karger.com & This article is licensed under the Creative Commons Attribution- \\
www.karger.com/ijd & NonCommercial-NoDerivatives 4.0 International License (CC BY- \\
NC-ND) (http://www.karger.com/Services/OpenAccessLicense). \\
Usage and distribution for commercial purposes as well as any dis- \\
tribution of modified material requires written permission.
\end{tabular}

indicated abdominal obesity, elevated body mass index, and dyslipidemia with increased levels of total cholesterol and triglycerides as well as reduced high-density lipoprotein cholesterol in CAD subjects compared to healthy controls $(p<0.05)$. Logistic regression analysis of the data revealed an association of the RR genotype of the Q192R polymorphism with an about 2-fold elevated risk of CAD (OR $=2.23,95 \%$ $\mathrm{Cl}=1.47-3.37, p=0.0001)$. Contrariwise, the L55M polymorphism did not show significant association with CAD (OR = $1.81,95 \% \mathrm{Cl}=0.66-4.95, p=0.326)$. Conclusions: The $\mathrm{Q} 192 \mathrm{R}$ polymorphism in the PON1 gene may be a susceptibility gene associated with increased risk of CAD in an Asian Indian population.

(c) 2018 The Author(s)

Published by S. Karger AG, Basel

\section{Introduction}

Cardiovascular diseases (CVDs), including coronary artery disease (CAD) and stroke, have emerged as major health conditions associated with high mortality and pronounced socioeconomic burden in the developing coun-
Dr. Jasvinder Singh Bhatti

Department of Biotechnology

Sri Guru Gobind Singh College

Chandigarh 160019 (India)

E-Mail jasvinderbhatti@yahoo.com 
Fig. 1. Digested PCR product of the PON1 (Q192R and L55M) gene polymorphism with HinfI restriction enzyme. Lane $M$ : 100-bp marker ladder; lanes 1, 2: 144 bp (MM); lanes 3, 4: 122 bp (LL); lanes 5, 6: $144 \mathrm{bp}$ and $122 \mathrm{bp}$ (LM); lanes 7, 8: $111 \mathrm{bp}$ (QQ); lanes 9-11: $111 \mathrm{bp}$ and $77 \mathrm{bp}$ (QR); lane 12: $77 \mathrm{bp}$ (RR). PON1, paraoxonase 1 .

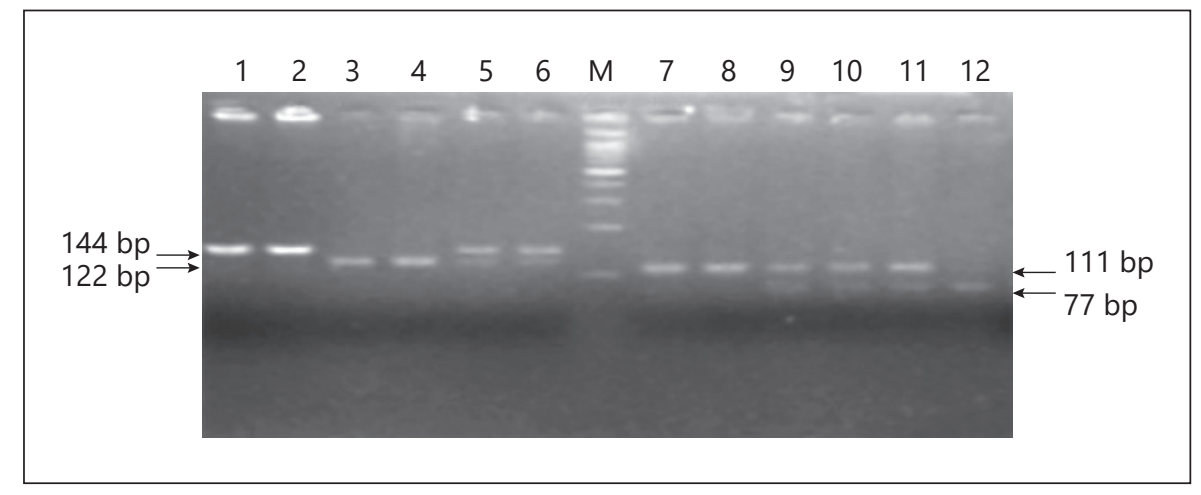

tries. Currently in India, there are 270 deaths/10,000 people from CVDs [1]. Recent estimates predict that India lost about USD 237 billion on healthcare expenditure in the last decade (2005-2015) due to the exponential increase in the burden of CVDs [2]. CAD is a multifactorial disease in which interactions among various environmental and genetic determinants play a critical role in pathophysiology [3, 4]. Recent studies revealed an association of single nucleotide polymorphisms (SNPs) in various genes with the augmented risk of developing CAD in many populations. Serum paraoxonase 1 (PON1) is one of the susceptibility genes which play a significant role in vascular pathology, and thus is regarded as an emergent biomarker of CAD. It is a $44-\mathrm{kDa} \mathrm{Ca}^{2+}$-dependent glycoprotein enzyme produced in the liver and bound to the surface of high-density lipoproteins (HDLs). PON1 is released into the blood by the liver, where it associates primarily with HDL [5] and is regarded to be a key factor for the antioxidative activity of HDL [6]. The PON1 gene has several SNPs [7]; however, the extensively studied SNPs are those in the coding regions, i.e., Q192R (rs662) and L55M (rs854560) [8]. The Q192R polymorphism, represented by an exchange of glutamine $(\mathrm{Q})$ to arginine $(\mathrm{R})$, may disturb the antioxidative potential of Arg192 and lead to greater risk of developing $\mathrm{CAD}$ [9]. There is another polymorphism of the PON1 gene, L55M, in which leucine to methionine substitution occurring at amino acid 55 has been associated with reduced PON1 activity [10]. Earlier studies showed that L55M genetic polymorphism may be related with cerebrovascular disease and CAD [11]. Some studies have been reported in Asian Indians, but were concentrated on the other parts of India. So, the present study was devised to examine the genetic interplay of PON1 gene polymorphisms (Q192R and L55M) and modifiable lifestyle-related factors associated with the risk of CAD in an Asian Indian population.

PON1 Gene Polymorphisms and

Coronary Artery Disease in Asian Indians

\section{Materials and Methods}

\section{Study Subjects}

The present study included 872 human subjects, among whom 460 were healthy controls and 412 were angiographically confirmed CAD patients. All these subjects were a part of our ongoing study on diabetes and CVD [12]. In brief, this study was launched in year 2011 to inspect the susceptibility genes and their association with the pathophysiology of metabolic disorders, including type 2 diabetes and CVDs, in an Asian Indian population. CAD was diagnosed by a cardiologist from the medical records showing medical indications, disturbed cardiac enzymes, ECG variations, and the outcomes of angiography and/or echocardiography. The study was explained to each participant and then information was collected regarding age, sex, educational qualifications, physical inactivity, diet, family history of CAD, smoking, alcohol consumption, etc.

\section{Inclusion/Exclusion Criteria}

Individuals aged $>35$ years, irrespective of their disease status, were involved in this study. Participants belonging to north Indian states only (Punjab, Haryana, and Chandigarh) were included in this study. Controls having a family history of CVD, type 2 diabetes, osteoporosis, other bone disorders, or cancer were excluded from the study.

\section{Anthropometric and Clinical Measurements}

Standard anthropometric measurements including height, weight, as well as waist and hip circumference were performed in all participants using standard procedures. Blood pressure was measured using an Omron blood pressure meter. Fasting blood samples were collected for clinical estimations, including serum glucose, total cholesterol, triglyceride, HDL, and creatinine levels using standard kits. All derived measures, including body mass index (BMI), body fat percentage, low-density lipoprotein (LDL) cholesterol, and very-low-density lipoprotein (VLDL) cholesterol, were calculated using standard formulae. Phenotypic characterizations, such as hypertension, obesity, and dyslipidemia, were completed according to the values recommended for Asian Indians only.

\section{Genotyping of the PON1 Gene}

Genomic DNA was extracted from nucleated blood cells using phenol/chloroform/isoamyl alcohol. The PON1 gene was amplified to detect the Q192R polymorphism using the following primers: 
Table 1. Anthropometric and clinical parameters in CAD patients and controls

\begin{tabular}{|c|c|c|c|c|c|}
\hline \multirow[t]{2}{*}{ Parameters } & \multicolumn{2}{|c|}{ Controls } & \multicolumn{2}{|c|}{ CAD patients } & \multirow{2}{*}{$\begin{array}{l}p \\
\text { value }\end{array}$} \\
\hline & mean & SD & mean & $\mathrm{SD}$ & \\
\hline Age, years & 56.21 & 12.78 & 56.81 & 10.55 & 0.414 \\
\hline Height, cm & 161.96 & 9.28 & 164.77 & 7.86 & 0.000 \\
\hline Weight, kg & 67.29 & 12.71 & 66.64 & 12.55 & 0.410 \\
\hline $\mathrm{BMI}, \mathrm{kg} / \mathrm{m}^{2}$ & 25.69 & 4.64 & 24.51 & 4.10 & 0.000 \\
\hline $\mathrm{WC}, \mathrm{cm}$ & 88.19 & 11.51 & 90.68 & 10.47 & 0.000 \\
\hline WHR & 0.94 & 0.08 & 0.99 & 0.06 & 0.000 \\
\hline Body fat, $\%$ & 32.67 & 10.14 & 29.31 & 9.15 & 0.000 \\
\hline Systolic BP, mm Hg & 129.50 & 21.45 & 133.38 & 19.83 & 0.003 \\
\hline Diastolic BP, mm Hg & 79.43 & 9.69 & 83.16 & 11.13 & 0.000 \\
\hline Glucose, mg/dL & 93.03 & 10.99 & 97.08 & 11.10 & 0.000 \\
\hline Cholesterol, mg/dL & 179.77 & 37.4 & 151.99 & 43.86 & 0.000 \\
\hline TGs, mg/dL & 150.00 & & & 63.78 & 0.494 \\
\hline $\mathrm{HDL}, \mathrm{mg} / \mathrm{dL}$ & 45.52 & 7.54 & 43.23 & 6.49 & 0.000 \\
\hline $\mathrm{LDL}, \mathrm{mg} / \mathrm{dL}$ & 104.25 & 36.75 & 79.32 & 41.40 & 0.000 \\
\hline VLDL, mg/dL & 30.00 & 13.26 & 29.44 & 12.76 & 0.494 \\
\hline Total lipids, mg/dL & 509.50 & 112.50 & 451.10 & 124.30 & 0.000 \\
\hline TC/HDL ratio & 4.06 & 1.13 & 3.60 & 1.24 & 0.000 \\
\hline LDL/HDL ratio & 2.37 & 0.99 & 1.89 & 1.09 & 0.000 \\
\hline TG/HDL ratio & 3.44 & 1.89 & 3.55 & 1.94 & 0.357 \\
\hline Creatinine, $\mathrm{mg} / \mathrm{dL}$ & 0.85 & 0.67 & 0.98 & 0.34 & 0.001 \\
\hline
\end{tabular}

$p$ values $<0.05$ were considered significant. BMI, body mass index; BP, blood pressure; CAD, coronary artery disease; HDL, highdensity lipoprotein; LDL, low-density lipoprotein; SD, standard deviation; TC, total cholesterol; TG, triglyceride; VLDL, very-lowdensity lipoprotein; WC, waist circumference; WHR, waist to hip ratio.

forward, 5'-TTG AAT GAT ATT GTT GCT GTG GGA CCT GAG3'; reverse, 5'-CGA CCA CGC TAA ACC CAA ATA CAT CTC CCA GAA- $3^{\prime}$. The amplification was done in $20 \mu \mathrm{L}$ reaction mixture containing 100-200 ng genomic DNA, $1 \times$ Taq DNA polymerase buffer, $2.5 \mathrm{mM}$ of $\mathrm{MgCl}_{2}, 10 \mathrm{pmol}$ of each primer, $200 \mu \mathrm{mol} / \mathrm{L}$ of dNTPs, and $1 \mathrm{U}$ of Taq DNA polymerase enzymes (Thermo) using a thermal cycler (Eppendorf). The PCR conditions were: initial denaturation at $94^{\circ} \mathrm{C}$ for $5 \mathrm{~min}$, followed by 35 cycles of denaturation at $94^{\circ} \mathrm{C}$ for $45 \mathrm{~s}$; annealing at $60^{\circ} \mathrm{C}$ for $45 \mathrm{~s}$; and then extension at $72^{\circ} \mathrm{C}$ for $45 \mathrm{~s}$, with a final extension step at $72^{\circ} \mathrm{C}$ for $10 \mathrm{~min}$. Figure 1 (right side) shows the amplified PCR products of $111 \mathrm{bp}$ digested with restriction enzyme - Hinfl (New England Biolabs) - and then resolved on 3\% agarose gel electrophoresis for the Q192R genotypes (QQ [111 bp], QR [111 and $77 \mathrm{bp}$ ], and RR [77 bp]).

For detection of the L55M gene polymorphism, we used the following primers: forward, $5^{\prime}$-GAG TGA TGT ATA GCC CCA GTT TC-3'; reverse, 5'-AGT CCA TTA GGC AGT ATC TCC G-3. We amplified the L55M gene polymorphism using similar PCR conditions in a $20-\mu \mathrm{L}$ reaction mixture. The amplified PCR product of $144 \mathrm{bp}$ was then digested with HinfI restriction enzyme at $37^{\circ} \mathrm{C}$ overnight. Figure 1 (left side) shows the digested product resolved on $3 \%$ agarose gel electrophoresis. The three genotypes were as follows: MM (144 bp), LM (144 and 122 bp), and LL (122 bp).

\section{Statistical Analysis}

Quantitative measures were expressed as mean \pm standard deviation. One-way ANOVA was applied to compare the normally distributed variables among various genotypes. Categorical variables were presented as percentage of cases and analyzed with Pearson's $\chi^{2}$ test. $p$ values $<0.05$ (two-tailed) were considered significant. Logistic regression analysis was done to associate various clinical parameters with genotypes. ORs were calculated with $95 \%$ CIs. All statistical analyses were carried out using the Statistical Package for the Social Sciences for Windows (SPSS), version 20.0 (IBM, Chicago, IL, USA).

\section{Results}

\section{Baseline Characteristics of the Study Population}

Of the 872 participants included in this study, 412 were angiographically proven CAD patients and 460 were healthy subjects. Smoking and alcohol consumption were significantly higher in CAD subjects compared to controls $(p<0.001)$. Table 1 summarizes the anthropometric and clinical characteristics of the study subjects. The mean age of healthy controls and CAD patients was 56.21 \pm 12.78 and $56.81 \pm 10.55$ years, respectively. Controls showed significantly higher BMI values compared to CAD patients $(25.69 \pm 4.64$ vs. $24.51 \pm 4.1, p<0.001)$. Central obesity, revealed by higher waist circumference and waist to hip ratio, was significantly prominent in CAD patients compared to controls, even at normal BMI values recommended for Asian Indians (Table 1). Significantly higher values of body fat percentage as well as systolic and diastolic blood pressure were observed in CAD patients compared to controls $(p<0.001)$. More than $85 \%$ of CAD patients were regularly taking lipid-lowering drugs to maintain their adverse lipid profile, due to which CAD patients might show normal values of total cholesterol, LDL, VLDL, and total lipids. Contrariwise, significantly lower HDL cholesterol, total cholesterol/HDL, and $\mathrm{LDL} / \mathrm{HDL}$ ratio were found in CAD patients compared to controls. Creatinine levels were significantly higher in CAD subjects than controls, indicating some nephrological complications. Although fasting glucose levels in both controls and CAD cases were normal, elevated fasting blood glucose values were observed in CAD subjects compared to healthy controls.

\section{Genotype Distribution in CAD Patients and Healthy Controls}

The distribution of genotypes and allelic frequencies for the Q192R polymorphism of the PON1 gene are shown in Table 2. The frequencies of the QQ, QR, and RR
Kaur/Bhatti/Vijayvergiya/Singh/Mastana/ Tewari/Bhatti 
Table 2. Distribution of genotype and allele frequencies of PON1 (Q192R and L55M) polymorphisms in CAD patients and controls

\begin{tabular}{|c|c|c|c|c|c|}
\hline \multirow[t]{2}{*}{ Genotypes } & \multirow{2}{*}{$\begin{array}{l}\text { Controls, } \\
n \text { (f) }\end{array}$} & \multirow{2}{*}{$\begin{array}{l}\text { CAD patients, } \\
n(\mathrm{f})\end{array}$} & \multicolumn{3}{|c|}{ Test of association } \\
\hline & & & $p$ value & OR & $95 \% \mathrm{CI}$ \\
\hline \multicolumn{6}{|c|}{ Q192R polymorphism } \\
\hline Total & 460 & 412 & & & \\
\hline QQ & $235(51.1)$ & $155(37.6)$ & \multicolumn{3}{|c|}{ reference } \\
\hline QR & $176(38.3)$ & $185(44.9)$ & $<0.0001$ & 1.59 & $1.19-2.12$ \\
\hline RR & $49(10.7)$ & $72(17.5)$ & $<0.0001$ & 2.23 & $1.47-3.37$ \\
\hline \multicolumn{6}{|c|}{ Allele frequency } \\
\hline Q & 0.70 & 0.60 & \\
\hline $\mathrm{R}$ & 0.30 & 0.40 & $<0.0001$ & & \\
\hline \multicolumn{6}{|c|}{ L55M polymorphism } \\
\hline Total & 460 & 412 & & & \\
\hline MM & $11(2.4)$ & $6(1.5)$ & \multicolumn{3}{|c|}{ reference } \\
\hline LM & $145(31.5)$ & $106(25.7)$ & 0.621 & 1.34 & $0.48-3.74$ \\
\hline LL & $304(66.1)$ & $300(72.8)$ & 0.326 & 1.81 & $0.66-4.95$ \\
\hline \multicolumn{6}{|c|}{ Allele frequency } \\
\hline $\mathrm{L}$ & 0.82 & 0.86 & \multirow[t]{2}{*}{0.031} & & \\
\hline M & 0.18 & 0.14 & & & \\
\hline
\end{tabular}

Bold indicates statistical significance $(p<0.05)$. CAD, coronary artery disease; PON1, paraoxonase 1.

genotypes of the PON1 gene Q192R polymorphism in CAD patients and controls were $37.6,44.9$, and $17.5 \%$ vs. $51.1,38.3$, and $10.7 \%$, respectively. A significantly higher frequency of RR genotype was observed in CAD patients than in controls $(p<0.0001)$. Logistic regression analysis of the data revealed that the heterozygous genotype $(\mathrm{QR})$ in the PON1 gene might be associated with an about 1.6 fold augmented risk of developing CAD in an Indian population (odds ratio $[\mathrm{OR}]=1.59,95 \% \mathrm{CI}=1.19-2.12$, $p<0.0001$ ), whereas the QR genotype might be associated with an about 2.2-fold augmented risk $(\mathrm{OR}=2.23$, $95 \% \mathrm{CI}=1.47-3.37, p<0.0001)$. When the data were stratified according to the anthropometric and biochemical characteristics of all the subjects according to the genotypes QQ, QR, and RR of the PON1 Q192R polymorphism, no significant differences were observed between the genotype in CAD patients and that in controls (Table 3). Although an uneven distribution of some of the clinical parameters was observed in both cases and controls, all were nonsignificant.

The distribution of genotype and allelic frequencies for the L55M polymorphism of the PON1 gene is illustrated in Table 2. The frequencies of the MM, LM, and LL genotypes of PON1 gene L55M polymorphism in controls versus CAD patients were $2.4,31.5$, and $66.1 \%$ versus $1.5,25.7$, and $72.8 \%$, respectively. No significant dif- ferences were prominent in the distribution of L55M genotypes among the controls and CAD patients. The frequency of the $\mathrm{L}$ allele was higher than that of the $\mathrm{M}$ allele in both CAD patients and controls. Logistic regression data analysis did not establish a significant association of the LL genotype with CAD $(\mathrm{OR}=1.81,95 \% \mathrm{CI}=$ $0.66-4.95, p=0.326)$. Similar to the Q192R polymorphism, we stratified all anthropometric and biochemical characteristics of the CAD patients and controls according to the genotypes LL, LM, and MM of the PON1 L55M polymorphism, but did not observe significant differences among the various genotypes in CAD patients or controls (Table 4).

\section{Discussion}

The escalation of incidence and prevalence of CVDs in India has become a major public health issue associated with social, personal, and economic burden for individuals, families, and state healthcare system [1]. A recent study established a higher risk of developing CVD among north Indians compared to inhabitants of other parts of India [13]. There are many risk factors which contribute to the present epidemic situation of CVDs in Indian populations. Various studies reported an association of envi- 
Table 3. Distribution of metabolic characteristics in controls and CAD patients according to the genotypes of the Q192R polymorphism in the PON1 gene

\begin{tabular}{|c|c|c|c|c|c|c|c|}
\hline \multirow[t]{2}{*}{ Parameters } & \multirow[t]{2}{*}{ Genotypes } & \multicolumn{3}{|c|}{ Controls } & \multicolumn{3}{|c|}{ CAD patients } \\
\hline & & mean & SD & $p$ value & mean & SD & $p$ value \\
\hline \multirow[t]{3}{*}{ BMI, kg/m² } & QQ & 26.23 & 4.69 & \multirow[t]{3}{*}{0.559} & 23.13 & 4.99 & \multirow[t]{3}{*}{0.532} \\
\hline & QR & 25.20 & 4.57 & & 23.65 & 3.52 & \\
\hline & $\mathrm{RR}$ & 24.92 & 4.06 & & 24.57 & 2.71 & \\
\hline \multirow[t]{3}{*}{$\mathrm{WC}, \mathrm{cm}$} & QQ & 90.88 & 9.05 & \multirow[t]{3}{*}{0.991} & 89.63 & 15.30 & \multirow[t]{3}{*}{0.397} \\
\hline & QR & 90.79 & 8.69 & & 90.89 & 9.15 & \\
\hline & $\mathrm{RR}$ & 90.47 & 7.59 & & 94.31 & 8.52 & \\
\hline \multirow[t]{3}{*}{$\mathrm{HC}, \mathrm{cm}$} & QQ & 95.59 & 8.26 & \multirow[t]{3}{*}{0.712} & 91.59 & 9.62 & \multirow[t]{3}{*}{0.408} \\
\hline & QR & 94.05 & 7.76 & & 93.21 & 7.24 & \\
\hline & $\mathrm{RR}$ & 95.08 & 8.25 & & 95.17 & 5.74 & \\
\hline \multirow[t]{3}{*}{ WHR } & QQ & 0.95 & 0.07 & \multirow[t]{3}{*}{0.641} & 0.97 & 0.10 & \multirow[t]{3}{*}{0.712} \\
\hline & QR & 0.97 & 0.07 & & 0.98 & 0.06 & \\
\hline & $\mathrm{RR}$ & 0.95 & 0.07 & & 0.99 & 0.07 & \\
\hline \multirow[t]{3}{*}{ Body fat, $\%$} & QQ & 34.83 & 10.31 & \multirow[t]{3}{*}{0.756} & 29.79 & 9.77 & \multirow[t]{3}{*}{0.437} \\
\hline & QR & 33.14 & 9.41 & & 28.38 & 7.24 & \\
\hline & $\mathrm{RR}$ & 33.89 & 7.34 & & 31.30 & 10.59 & \\
\hline \multirow[t]{3}{*}{ Systolic BP, mm Hg } & QQ & 141.75 & 23.53 & \multirow[t]{3}{*}{0.112} & 130.40 & 19.63 & \multirow[t]{3}{*}{0.249} \\
\hline & QR & 137.54 & 21.70 & & 133.32 & 16.07 & \\
\hline & $\mathrm{RR}$ & 125.27 & 19.96 & & 140.81 & 24.98 & \\
\hline \multirow[t]{3}{*}{ Diastolic BP, mm Hg } & QQ & 82.13 & 11.89 & 0.305 & 83.33 & 12.91 & 0.903 \\
\hline & QR & 83.15 & 11.62 & & 82.02 & 9.41 & \\
\hline & $\mathrm{RR}$ & 77.18 & 7.82 & & 82.13 & 10.09 & \\
\hline Glucose, mg/dL & QQ & 99.06 & 6.63 & 0.053 & 105.75 & 10.91 & 0.526 \\
\hline & QR & 97.29 & 9.16 & & 99.00 & 11.21 & \\
\hline & $\mathrm{RR}$ & 91.80 & 8.16 & & 99.33 & 9.59 & \\
\hline Cholesterol, mg/dL & QQ & 184.38 & 36.63 & 0.385 & 143.33 & 39.93 & 0.621 \\
\hline & QR & 186.05 & 34.89 & & 134.84 & 42.52 & \\
\hline & $\mathrm{RR}$ & 201.45 & 40.14 & & 145.00 & 49.93 & \\
\hline TGs, mg/dL & QQ & 134.59 & 37.83 & 0.126 & 160.67 & 55.60 & 0.662 \\
\hline & QR & 158.44 & 58.17 & & 150.20 & 45.92 & \\
\hline & $\mathrm{RR}$ & 146.27 & 38.87 & & 161.15 & 73.76 & \\
\hline HDL, mg/dL & QQ & 43.44 & 2.59 & 0.390 & 42.33 & 4.20 & 0.473 \\
\hline & QR & 42.62 & 3.22 & & 43.48 & 3.44 & \\
\hline & $\mathrm{RR}$ & 43.64 & 2.66 & & 43.72 & 3.05 & \\
\hline $\mathrm{LDL}, \mathrm{mg} / \mathrm{dL}$ & QQ & 114.02 & 36.87 & 0.380 & 68.87 & 36.78 & 0.713 \\
\hline & QR & 111.75 & 33.23 & & 61.32 & 41.31 & \\
\hline & $\mathrm{RR}$ & 128.56 & 40.70 & & 69.05 & 48.26 & \\
\hline VLDL, mg/dL & QQ & 26.92 & 7.57 & 0.126 & 32.13 & 11.12 & 0.662 \\
\hline & QR & 31.69 & 11.64 & & 30.04 & 9.19 & \\
\hline & RR & 29.25 & 7.77 & & 32.23 & 14.75 & \\
\hline Total lipids, mg/dL & QQ & 503.30 & 86.90 & 0.324 & 447.30 & 119.90 & 0.528 \\
\hline & QR & 530.50 & 106.80 & & 419.80 & 109.80 & \\
\hline & $\mathrm{RR}$ & 549.20 & 98.40 & & 451.10 & 142.50 & \\
\hline
\end{tabular}


Table 3 (continued)

\begin{tabular}{|c|c|c|c|c|c|c|c|}
\hline \multirow[t]{2}{*}{ Parameters } & \multirow[t]{2}{*}{ Genotypes } & \multicolumn{3}{|c|}{ Controls } & \multicolumn{3}{|c|}{ CAD patients } \\
\hline & & mean & SD & $p$ value & mean & SD & $p$ value \\
\hline \multirow[t]{3}{*}{ TC/HDL ratio } & QQ & 4.27 & 0.95 & \multirow[t]{3}{*}{0.510} & 3.47 & 1.18 & \multirow[t]{3}{*}{0.594} \\
\hline & QR & 4.41 & 1.00 & & 3.16 & 1.16 & \\
\hline & $\mathrm{RR}$ & 4.67 & 1.19 & & 3.37 & 1.30 & \\
\hline \multirow[t]{3}{*}{ LDL/HDL ratio } & QQ & 2.64 & 0.92 & \multirow[t]{3}{*}{0.516} & 1.68 & 0.96 & \multirow[t]{3}{*}{0.683} \\
\hline & QR & 2.66 & 0.88 & & 1.45 & 1.04 & \\
\hline & $\mathrm{RR}$ & 3.00 & 1.10 & & 1.61 & 1.17 & \\
\hline \multirow[t]{3}{*}{ TG/HDL ratio } & QQ & 3.12 & 0.95 & \multirow[t]{3}{*}{0.101} & 3.92 & 1.72 & \multirow[t]{3}{*}{0.648} \\
\hline & QR & 3.78 & 1.56 & & 3.53 & 1.43 & \\
\hline & $\mathrm{RR}$ & 3.38 & 1.06 & & 3.80 & 2.12 & \\
\hline \multirow[t]{3}{*}{ Creatinine, mg/dL } & QQ & 0.92 & 1.88 & \multirow[t]{3}{*}{0.590} & 0.95 & 0.31 & \multirow[t]{3}{*}{0.892} \\
\hline & QR & 0.71 & 0.33 & & 0.94 & 0.37 & \\
\hline & $\mathrm{RR}$ & 0.53 & 0.17 & & 0.99 & 0.40 & \\
\hline
\end{tabular}

$p$ values denote differences among the genotypes in a particular condition. $p$ values $<0.05$ were considered significant. BMI, body mass index; $\mathrm{BP}$, blood pressure; CAD, coronary artery disease; HC, hip circumference; HDL, high-density lipoprotein; LDL, low-density lipoprotein; PON1, paraoxonase 1; SD, standard deviation; TC, total cholesterol; TG, triglyceride; VLDL, very-low-density lipoprotein; WC, waist circumference; WHR, waist to hip ratio.

ronmental risk factors with the development of CVDs $[14,15]$. In our previous study, we presented abdominal obesity, even at normal BMI, dyslipidemia, family history of $\mathrm{CAD}$, and cigarette smoking as independent risk factors for CAD in north Indians [16]. It was evident from earlier studies that Asian Indians develop CAD in the most dynamic period of their life and at least a decade earlier than Caucasians [17].

Several studies have documented the role of SNPs in various genes in the escalating risk of CAD [18, 19]. PON1 is known to play important roles such as an antioxidant, anti-inflammatory, and antiatherosclerotic functions by preventing LDL oxidation [20]. Moreover, PON1 inhibits the accumulation of oxidized LDL and speeds up cholesterol efflux from macrophages [21, 22]. Some studies extensively studied the Q192R and L55M polymorphisms in PON1 in different populations and exhibited the pathogenesis of CVDs [23]. PON1 may be atheroprotective $[24,25]$, and genetic variations in the PON1 gene may affect its ability to protect against CVDs. The present study established an association of the RR genotype of the Q192R polymorphism with a two-fold amplified risk of $\mathrm{CAD}$ in a north Indian population. Also, the frequency of mutant allele (R) in the 192R$\mathrm{PON} 1$ gene among CAD patients was comparable to that in previous studies conducted in Indian populations. Our results are in line with an earlier study done in a northwest Punjabi population where the QR and RR genotypes contributed to increased CAD development [26]. Many other studies documented a relationship of the Q192R polymorphism with an increased risk of CAD in Asian Indian populations [10,27-31], Caucasians [9, 32], and Japanese [33], but negative results have been reported in Korean [34], Spanish [35], Italian [36], British Caucasian [37, 38], and Polish [39] populations. Metaanalyses of various studies also confirmed an association of the $192 \mathrm{R}$ variant with the risk of CAD development $[40,41]$. However, no significant association of the $192 \mathrm{R}$ genotype with CAD was reported in a Taiwanese population [42]. Interestingly, various Asian, Indian, European Caucasian, and Saudi Arabian populations revealed comparable frequency of the alleles [43], while some African black populations have a significantly higher frequency of the PON1 192Q allele [44]. These inconsistencies in the association of the Q192R genotype with high $\mathrm{CAD}$ risk may be due to sample size, differences in ethnicity, genotyping methods, as well as gene-gene and gene-environment interactions [43]. We did not find any significant association of the RR genotype in the PON1 gene with metabolic traits in CAD patients or controls. 
Table 4. Distribution of metabolic characteristics in controls and CAD patients according to the genotypes of the L55M polymorphism in the PON1 gene

\begin{tabular}{|c|c|c|c|c|c|c|c|}
\hline \multirow[t]{2}{*}{ Parameters } & \multirow[t]{2}{*}{ Genotypes } & \multicolumn{3}{|c|}{ Controls } & \multicolumn{3}{|c|}{ CAD patients } \\
\hline & & mean & SD & $p$ value & mean & SD & $p$ value \\
\hline \multirow[t]{3}{*}{ BMI, $\mathrm{kg} / \mathrm{m}^{2}$} & LL & 25.05 & 6.02 & \multirow[t]{3}{*}{0.824} & 23.57 & 1.97 & \multirow[t]{3}{*}{0.412} \\
\hline & LM & 22.87 & 3.87 & & 22.81 & 3.09 & \\
\hline & $\mathrm{MM}$ & 24.13 & 7.46 & & 24.31 & 3.99 & \\
\hline \multirow[t]{3}{*}{$\mathrm{WC}, \mathrm{cm}$} & LL & 88.95 & 13.40 & \multirow[t]{3}{*}{0.646} & 92.89 & 6.77 & \multirow[t]{3}{*}{0.224} \\
\hline & LM & 95.52 & 12.91 & & 86.59 & 7.63 & \\
\hline & MM & 89.08 & 16.56 & & 92.18 & 11.24 & \\
\hline \multirow[t]{3}{*}{$\mathrm{HC}, \mathrm{cm}$} & LL & 92.52 & 12.95 & \multirow[t]{3}{*}{0.546} & 93.70 & 5.28 & \multirow[t]{3}{*}{0.430} \\
\hline & $\mathrm{LM}$ & 94.52 & 7.75 & & 91.02 & 6.03 & \\
\hline & MM & 88.71 & 10.25 & & 94.65 & 9.42 & \\
\hline \multirow[t]{3}{*}{ WHR } & LL & 0.96 & 0.04 & \multirow[t]{3}{*}{0.661} & 0.99 & 0.06 & \multirow[t]{3}{*}{0.286} \\
\hline & LM & 1.01 & 0.08 & & 0.95 & 0.06 & \\
\hline & MM & 1.00 & 0.13 & & 0.97 & 0.06 & \\
\hline \multirow[t]{3}{*}{ Body fat, $\%$} & LL & 33.50 & 9.07 & \multirow[t]{3}{*}{0.383} & 26.57 & 4.35 & \multirow[t]{3}{*}{0.105} \\
\hline & LM & 33.78 & 6.30 & & 27.44 & 8.01 & \\
\hline & MM & 26.91 & 13.47 & & 31.73 & 10.28 & \\
\hline \multirow[t]{3}{*}{ Systolic BP, mm Hg } & LL & 122.00 & 13.04 & \multirow[t]{3}{*}{0.235} & 134.29 & 12.23 & \multirow[t]{3}{*}{0.864} \\
\hline & LM & 132.86 & 26.33 & & 137.36 & 14.89 & \\
\hline & $\mathrm{MM}$ & 116.25 & 10.61 & & 136.88 & 18.27 & \\
\hline \multirow[t]{3}{*}{ Diastolic BP, mm Hg } & LL & 79.00 & 18.84 & 0.684 & 83.57 & 11.51 & 0.762 \\
\hline & LM & 83.00 & 9.56 & & 85.73 & 8.39 & \\
\hline & MM & 76.88 & 12.80 & & 83.34 & 9.64 & \\
\hline Glucose, mg/dL & LL & 102.50 & 2.12 & 0.388 & 101.67 & 18.93 & 0.398 \\
\hline & LM & 87.60 & 10.78 & & 92.17 & 9.30 & \\
\hline & MM & 90.40 & 15.08 & & 98.68 & 11.19 & \\
\hline Cholesterol, mg/dL & $\mathrm{LL}$ & 163.29 & 12.76 & 0.531 & 138.44 & 55.33 & 0.856 \\
\hline & LM & 148.00 & 35.46 & & 135.45 & 47.03 & \\
\hline & MM & 141.77 & 38.74 & & 143.11 & 44.15 & \\
\hline TGs, mg/dL & LL & 142.28 & 18.85 & 0.928 & 150.56 & 73.86 & 0.248 \\
\hline & LM & 134.14 & 48.13 & & 124.91 & 27.46 & \\
\hline & MM & 143.85 & 63.84 & & 156.47 & 56.17 & \\
\hline $\mathrm{HDL}, \mathrm{mg} / \mathrm{dL}$ & LL & 42.09 & 5.68 & 0.101 & 43.35 & 3.99 & 0.798 \\
\hline & LM & 47.29 & 4.96 & & 42.36 & 3.61 & \\
\hline & MM & 40.99 & 5.90 & & 42.52 & 4.61 & \\
\hline $\mathrm{LDL}, \mathrm{mg} / \mathrm{dL}$ & LL & 92.74 & 19.85 & 0.419 & 64.98 & 55.42 & 0.948 \\
\hline & LM & 73.89 & 29.39 & & 68.11 & 46.78 & \\
\hline & MM & 72.01 & 31.85 & & 69.29 & 40.76 & \\
\hline VLDL, mg/dL & $\mathrm{LL}$ & 28.46 & 3.77 & 0.928 & 30.11 & 14.77 & 0.248 \\
\hline & LM & 26.83 & 9.63 & & 24.98 & 5.49 & \\
\hline & MM & 28.77 & 12.77 & & 31.29 & 11.23 & \\
\hline Total lipids, mg/dL & LL & 468.80 & 21.90 & 0.769 & 427.40 & 145.10 & 0.529 \\
\hline & LM & 430.10 & 109.10 & & 395.80 & 109.50 & \\
\hline & MM & 427.30 & 131.21 & & 442.60 & 125.90 & \\
\hline
\end{tabular}


Table 4 (continued)

\begin{tabular}{|c|c|c|c|c|c|c|c|}
\hline \multirow[t]{2}{*}{ Parameters } & \multirow[t]{2}{*}{ Genotypes } & \multicolumn{3}{|c|}{ Controls } & \multicolumn{3}{|c|}{ CAD patients } \\
\hline & & mean & SD & $p$ value & mean & SD & $p$ value \\
\hline \multirow[t]{3}{*}{ TC/HDL ratio } & LL & 3.97 & 0.86 & \multirow[t]{3}{*}{0.373} & 3.26 & 1.43 & \multirow[t]{3}{*}{0.850} \\
\hline & $\mathrm{LM}$ & 3.16 & 0.83 & & 3.27 & 1.36 & \\
\hline & $\mathrm{MM}$ & 3.53 & 1.11 & & 3.44 & 1.22 & \\
\hline \multirow[t]{3}{*}{ LDL/HDL ratio } & LL & 2.29 & 0.85 & \multirow[t]{3}{*}{0.321} & 1.55 & 1.34 & \multirow[t]{3}{*}{0.921} \\
\hline & LM & 1.58 & 0.66 & & 1.67 & 1.27 & \\
\hline & $\mathrm{MM}$ & 1.82 & 0.85 & & 1.69 & 1.05 & \\
\hline \multirow[t]{3}{*}{ TG/HDL ratio } & LL & 3.39 & 0.20 & \multirow[t]{3}{*}{0.616} & 3.58 & 2.13 & \multirow[t]{3}{*}{0.353} \\
\hline & $\mathrm{LM}$ & 2.90 & 1.17 & & 2.97 & 0.76 & \\
\hline & MM & 3.59 & 1.83 & & 3.77 & 1.67 & \\
\hline \multirow[t]{3}{*}{ Creatinine, $\mathrm{mg} / \mathrm{dL}$} & LL & 1.05 & 0.17 & \multirow[t]{3}{*}{0.197} & 0.85 & 0.17 & \multirow[t]{3}{*}{0.197} \\
\hline & LM & 0.95 & 0.19 & & 0.92 & 0.19 & \\
\hline & MM & 3.26 & 4.08 & & 0.98 & 0.27 & \\
\hline
\end{tabular}

$p$ values denote differences among the genotypes in a particular condition. $p$ values $<0.05$ were considered significant. BMI, body mass index; BP, blood pressure; CAD, coronary artery disease; HC, hip circumference; HDL, high-density lipoprotein; LDL, low-density lipoprotein; PON1, paraoxonase 1; SD, standard deviation; TC, total cholesterol; TG, triglyceride; VLDL, very-low-density lipoprotein; WC, waist circumference; WHR, waist to hip ratio.

However, previous findings proved an association between serum triglyceride levels and RR genotype [4547]. It is not clearly ascertained by which mechanism PON1 polymorphisms affect the level of serum triglycerides.

The present study did not show a significant association of PON1 (L55M) polymorphism with the risk of CAD in Asian Indians. Our results agreed with earlier studies showing that PON1-55 independently has no consequence on CAD $[10,30,40]$. Contrariwise, a study proposed the protective effect of the $\mathrm{M}$ allele of PON1 against CAD [48]. The LL genotype was observed to be a genetic risk factor for carotid atherosclerosis [49]. Another study observed a higher frequency of the PON1 L allele in CAD patients, thus establishing a significant connection of PON1 L55M polymorphism with CAD [50]. Some of the studies that were accomplished to demonstrate the relationship between the PON1-L55M polymorphism and CAD showed conflicting results [51]. In an Austrian population, it was seen that the L55M polymorphism was linked with CAD [49], whereas studies in other populations showed inconsistent results [30]. Our study showed a negative correlation between the L55M locus and CAD risk, and only the $\mathrm{M}$ allele was concluded to be a risk allele.

PON1 Gene Polymorphisms and Coronary Artery Disease in Asian Indians

\section{Conclusions}

The present study demonstrated a significant association of the Q192R polymorphism in the PON1 gene with an increased risk of $\mathrm{CAD}$, whereas no significant association was observed between the L55M polymorphism and CAD. Furthermore, metabolic traits were unaffected by variants of the PON1 gene in Asian Indians.

\section{Acknowledgment}

This study was financially supported by University Grants Commission (UGC), New Delhi under a Maulana Azad National Fellowship awarded to S. Kaur.

\section{Statement of Ethics}

Informed written consent was obtained from all participants. The study was approved by the institutional ethics committees of Panjab University, Chandigarh and Post Graduate Institute of Medical Education and Research, Chandigarh, India. All procedures were in accordance with the ethical standards of the institutional and/or national research committee and with the $1964 \mathrm{Hel}-$ sinki declaration and its later amendments or comparable ethical standards. 


\section{Disclosure Statement}

The authors have no conflicts of interest to declare.

\section{Author Contributions}

Study design and implementation: R. Tewari and J.S. Bhatti. Data collection and analysis: S. Kaur, G.K. Bhatti, R. Vijayvergiya, P. Singh, and S.S. Mastana. Manuscript drafting: S. Kaur, G.K. Bhatti, and J.S. Bhatti. Manuscript revision: all authors.

\section{References}

1 Prabhakaran D, Jeemon P, Roy A. Cardiovascular Diseases in India: Current Epidemiology and Future Directions. Circulation. 2016 Apr;133(16):1605-20.

2 Mendis S, Puska P, Norrving B, Organization WH. Global atlas on cardiovascular disease prevention and control. Geneva: World Health Organization; 2011.

3 Hirashiki A, Yamada Y, Murase Y, Suzuki Y, Kataoka H, Morimoto Y, et al. Association of gene polymorphisms with coronary artery disease in low- or high-risk subjects defined by conventional risk factors. J Am Coll Cardiol. 2003 Oct;42(8):1429-37.

4 Cooney MT, Dudina A, D’Agostino R, Graham IM. Cardiovascular risk-estimation systems in primary prevention: do they differ? Do they make a difference? Can we see the future? Circulation. 2010 Jul;122(3):300-10.

5 Deakin S, Leviev I, Gomaraschi M, Calabresi L, Franceschini G, James RW. Enzymatically active paraoxonase- 1 is located at the external membrane of producing cells and released by a high affinity, saturable, desorption mechanism. J Biol Chem. 2002 Feb; 277(6):4301-8.

6 Deakin SP, James RW. Genetic and environmental factors modulating serum concentrations and activities of the antioxidant enzyme paraoxonase-1. Clin Sci (Lond). 2004 Nov; 107(5):435-47.

7 Richter RJ, Jarvik GP, Furlong CE. Paraoxonase 1 status as a risk factor for disease or exposure. Adv Exp Med Biol. 2010;660:2935.

8 Costa LG, Cole TB, Jarvik GP, Furlong CE. Functional genomic of the paraoxonase (PON1) polymorphisms: effects on pesticide sensitivity, cardiovascular disease, and drug metabolism. Annu Rev Med. 2003;54(1):37192.

9 Serrato M, Marian AJ. A variant of human paraoxonase/arylesterase (HUMPONA) gene is a risk factor for coronary artery disease. J Clin Invest. 1995 Dec;96(6):3005-8.

10 Lakshmy R, Ahmad D, Abraham RA, Sharma $\mathrm{M}$, Vemparala K, Das S, et al. Paraoxonase gene Q192R \& L55M polymorphisms in Indians with acute myocardial infarction \& association with oxidized low density lipoprotein. Indian J Med Res. 2010 Apr;131:522-9.

11 Seo D, Goldschmidt-Clermont P. The paraoxonase gene family and atherosclerosis. Curr Atheroscler Rep. 2009 May;11(3):182-7.

12 Bhatti GK, Bhadada SK, Vijayvergiya R, Mastana SS, Bhatti JS. Metabolic syndrome and risk of major coronary events among the urban diabetic patients: North Indian Diabetes and Cardiovascular Disease StudyNIDCVD-2. J Diabetes Complications. 2016 Jan-Feb;30(1):72-8.

13 Geldsetzer P, Manne-Goehler J, Theilmann M, Davies JI, Awasthi A, Danaei G, et al. Geographic and sociodemographic variation of cardiovascular disease risk in India: A crosssectional study of 797,540 adults. PLoS Med. 2018 Jun;15(6):e1002581.

14 Gupta S, Gudapati R, Gaurav K, Bhise M. Emerging risk factors for cardiovascular diseases: Indian context. Indian J Endocrinol Metab. 2013 Sep;17(5):806-14.

15 Nag T, Ghosh A. Cardiovascular disease risk factors in Asian Indian population: A systematic review. J Cardiovasc Dis Res. 2013 Dec; 4(4):222-8.

16 Bhatti GK, Bhatti JS, Vijayvergiya R, Singh B. Implications of ACE (I/D) Gene Variants to the Genetic Susceptibility of Coronary Artery Disease in Asian Indians. Indian J Clin Biochem. 2017 Jun;32(2):163-70.

17 Joshi P, Islam S, Pais P, Reddy S, Dorairaj P, Kazmi K, et al. Risk factors for early myocardial infarction in South Asians compared with individuals in other countries. JAMA. 2007 Jan;297(3):286-94.

18 Winham SJ, de Andrade M, Miller VM. Genetics of cardiovascular disease: importance of sex and ethnicity. Atherosclerosis. $2015 \mathrm{Jul}$; 241(1):219-28.

19 Ehret GB, Munroe PB, Rice KM, Bochud M, Johnson AD, Chasman DI, et al.; CHARGEHF consortium. Genetic variants in novel pathways influence blood pressure and cardiovascular disease risk. Nature. 2011 Sep; 478(7367):103-9.

20 Litvinov D, Mahini H, Garelnabi M. Antioxidant and anti-inflammatory role of paraoxonase 1: implication in arteriosclerosis diseases. N Am J Med Sci. 2012 Nov;4(11):523-32.

21 Kowalska K, Socha E, Milnerowicz H. Review: the role of paraoxonase in cardiovascular diseases. Ann Clin Lab Sci. 2015;45(2):226-33.

22 Mackness MI, Arrol S, Durrington PN. Paraoxonase prevents accumulation of lipoperoxides in low-density lipoprotein. FEBS Lett. 1991 Jul;286(1-2):152-4.

23 Abelló D, Sancho E, Camps J, Joven J. Exploring the role of paraoxonases in the pathogenesis of coronary artery disease: a systematic review. Int J Mol Sci. 2014 Nov;15(11):209971010.

24 Durrington PN, Mackness B, Mackness MI. Paraoxonase and atherosclerosis. Arterioscler Thromb Vasc Biol. 2001 Apr;21(4):473-80.
25 Tward A, Xia YR, Wang XP, Shi YS, Park C, Castellani LW, et al. Decreased atherosclerotic lesion formation in human serum paraoxonase transgenic mice. Circulation. $2002 \mathrm{Jul}$ 106(4):484-90.

26 Gupta N, Singh S, Maturu VN, Sharma YP, Gill KD. Paraoxonase 1 (PON1) polymorphisms, haplotypes and activity in predicting cad risk in North-West Indian Punjabis. PLoS One. 2011;6(5):e17805.

27 Pati N, Pati U. Paraoxonase gene polymorphism and coronary artery disease in Indian subjects. Int J Cardiol. 1998 Sep;66(2):165-8.

28 Matam K, Khan IA, Hasan Q, Rao P. Coronary artery disease and the frequencies of MTHFR and PON1 gene polymorphism studies in a varied population of Hyderabad, Telangana region in south India. J King Saud Univ Sci. 2015;27(2):143-50.

29 Ganesan M, Bhaskar S, Mani R, Idris MM, Khaja N, Gulla S, et al. The relationship of $\mathrm{ACE}$ and CETP gene polymorphisms with cardiovascular disease in a cohort of Asian Indian patients with and those without type 2 diabetes. J Diabetes Complications. 2011 SepOct:25(5):303-8.

30 Agrawal S, Tripathi G, Prajnya R, Sinha N, Gilmour A, Bush L, et al. Paraoxonase 1 gene polymorphisms contribute to coronary artery disease risk among north Indians. Indian J Med Sci. 2009 Aug;63(8):335-44.

31 Ahmad I, Narang R, Venkatraman A, Das N. Two- and three-locus haplotypes of the paraoxonase (PON1) gene are associated with coronary artery disease in Asian Indians. Gene. 2012 Sep;506(1):242-7.

32 Bhattacharyya T, Nicholls SJ, Topol EJ, Zhang R, Yang X, Schmitt D, et al. Relationship of paraoxonase 1 (PON1) gene polymorphisms and functional activity with systemic oxidative stress and cardiovascular risk. JAMA. 2008 Mar;299(11):1265-76.

33 Odawara M, Tachi Y, Yamashita K. Paraoxonase polymorphism (Gln192-Arg) is associated with coronary heart disease in Japanese noninsulin-dependent diabetes mellitus. J Clin Endocrinol Metab. 1997 Jul;82(7):2257-60.

34 Hong SH, Song J, Min WK, Kim JQ. Genetic variations of the paraoxonase gene in patients with coronary artery disease. Clin Biochem. 2001 Sep;34(6):475-81.

35 Ferré N, Tous M, Paul A, Zamora A, Vendrell JJ, Bardají A, et al. Paraoxonase Gln-Arg(192) and Leu-Met(55) gene polymorphisms and enzyme activity in a population with a low rate of coronary heart disease. Clin Biochem. 2002 May;35(3):197-203. 
36 Ombres D, Pannitteri G, Montali A, Candeloro A, Seccareccia F, Campagna F, et al. The Gln-Arg192 polymorphism of human paraoxonase gene is not associated with coronary artery disease in Italian patients. Arterioscler Thromb Vasc Biol. 1998 Oct;18(10):1611-6.

37 Lawlor DA, Day IN, Gaunt TR, Hinks LJ, Briggs PJ, Kiessling M, et al. The association of the PON1 Q192R polymorphism with coronary heart disease: findings from the British Women's Heart and Health cohort study and a meta-analysis. BMC Genet. 2004 Jun;5(1): 17.

38 Robertson KS, Hawe E, Miller GJ, Talmud PJ, Humphries SE; Northwick Park Heart Study II. Human paraoxonase gene cluster polymorphisms as predictors of coronary heart disease risk in the prospective Northwick Park Heart Study II. Biochim Biophys Acta. 2003 Nov;1639(3):203-12.

39 Balcerzyk A, Zak I, Krauze J. Synergistic effects between Q192R polymorphism of paraoxonase 1 gene and some conventional risk factors in premature coronary artery disease. Arch Med Res. 2007 Jul;38(5):545-50.

40 Wheeler JG, Keavney BD, Watkins H, Collins $\mathrm{R}$, Danesh J. Four paraoxonase gene polymorphisms in 11212 cases of coronary heart disease and 12786 controls: meta-analysis of 43 studies. Lancet. 2004 Feb;363(9410):689-95.
41 Mackness B, Davies GK, Turkie W, Lee E, Roberts DH, Hill E, et al. Paraoxonase status in coronary heart disease: are activity and concentration more important than genotype? Arterioscler Thromb Vasc Biol. 2001 Sep;21(9):1451-7.

42 Ko YL, Ko YS, Wang SM, Hsu LA, Chang CJ, Chu PH, et al. The Gln-Arg 191 polymorphism of the human paraoxonase gene is not associated with the risk of coronary artery disease among Chinese in Taiwan. Atherosclerosis. 1998 Dec;141(2):259-64.

43 Hassan MA, Al-Attas OS, Hussain T, AlDaghri NM, Alokail MS, Mohammed AK, et al. The Q192R polymorphism of the paraoxonase 1 gene is a risk factor for coronary artery disease in Saudi subjects. Mol Cell Biochem. 2013 Aug;380(1-2):121-8.

44 Scacchi R, Gambina G, Martini MC, Broggio E, Vilardo T, Corbo RM. Different pattern of association of paraoxonase Gln192->Arg polymorphism with sporadic late-onset Alzheimer's disease and coronary artery disease. Neurosci Lett. 2003 Mar;339(1):17-20.

45 Hegele RA, Brunt JH, Connelly PW. A polymorphism of the paraoxonase gene associated with variation in plasma lipoproteins in a genetic isolate. Arterioscler Thromb Vasc Biol. 1995 Jan;15(1):89-95.
46 Saha N, Roy AC, Teo SH, Tay JS, Ratnam SS. Influence of serum paraoxonase polymorphism on serum lipids and apolipoproteins. Clin Genet. 1991 Oct;40(4):277-82.

47 Bounafaa A, Berrougui H, Ghalim N, Nasser B, Bagri A, Moujahid A, et al. Association between Paraoxonase 1 (PON1) Polymorphisms and the Risk of Acute Coronary Syndrome in a North African Population. PLoS One. 2015 Aug; 10(8):e0133719.

48 Oliveira SA, Mansur AP, Ribeiro CC, Ramires JA, Annichino-Bizzacchi JM. PON1 M/L55 mutation protects high-risk patients against coronary artery disease. Int J Cardiol. 2004 Mar;94(1):73-7.

49 Schmidt H, Schmidt R, Niederkorn K, Gradert A, Schumacher M, Watzinger N, et al. Paraoxonase PON1 polymorphism leuMet54 is associated with carotid atherosclerosis: results of the Austrian Stroke Prevention Study. Stroke. 1998 Oct;29(10):2043-8.

50 Taşkiran P, Cam SF, Sekuri C, Tüzün N, Alioğlu E, Altintaş N, et al. The relationship between paraoxonase gene Leu-Met (55) and Gln-Arg (192) polymorphisms and coronary artery disease. Turk Kardiyol Dern Ars. 2009 Oct:37(7):473-8.

51 Mackness MI, Durrington PN, Mackness B. How high-density lipoprotein protects against the effects of lipid peroxidation. Curr Opin Lipidol. 2000 Aug;11(4):383-8. 